\title{
Good Stuff Cheap
}

\author{
Jerry Ellis \\ Founder and GEO, Building \#19
}

$B$ uilding \#19, eponymously named for its original warehouse in Hingham, Massachusetts, is either the largest or the second largest salvage operation in the United States, depending on how you measure the competition. But Jerry Ellis, founder and CEO, does not care which position his company is in, as long as he can run Building $\# 19$ with his special mix of bargains, planned chaos, and humor. Always humor.

Building \#19 grew out of necessity the necessity to put food on the table for a growing (and hungry) family. In 1964, an unemployed and bankrupt Jerry Ellis tried something new with an old friend. Using their skills in marketing and bargain hunting, they set up a part-time retail business selling insurance loss furniture. This went well, and the store began to flourish, selling salvage, mail order returns, closeouts, bankruptcy stocks, irregulars, and overstocks. In the intervening 35 years, Building \#19 has grown to 14 stores in Massachusetts, New Hampshire, and Rhode Island. Each store is named with a fraction added to the original store name: Building \#19 1/2 in Woburn, Massachusetts, was the second store to open (1970) and Building \#19 1/3 is the most recently opened, in Hanover, Massachusetts.

Widely known for creative advertising, astoundingly diverse stock, and bargains, bargains, bargains, Building \#19 is an intriguing organization with an unusual CEO and an iconoclastic approach to successful business. Ellis and NEJE contributor Gina Vega talked web sites, commerce both $e$ - and otherwise-and strategy.

NEJE: You are among the very largest salvage operations in the nation. How did you get here?

Ellis: One customer at a time. We tried to do it right. We took care of our customers as well as our employees. And, we worked hard. When I started this business in 1964, I was a recent bankrupt. I was jobless and I had to establish myself. There was no shortage of retailers, so I knew that I had to develop a personality for the business.

I wanted it to be an honest business and so the store developed from my personality, which is to poke fun at myself to personalize things. People like to do business with people; they don't like to do business with companies.

NEJE: How about doing business via the Internet? Is there a place for Building \#19 on the net?
Ellis: Yes, but not a major place. Since everything we buy is a one-shot deal, I want that stuff to be in the stores. When people come in for that item, they also buy a pair of pants or whatever while they happen to be at the store. If we sell on the web site, it's that one item and that's it. My view is probably not very refined, but that's the way I see it. My object in advertising is to get feet into the store and if I do that they'll buy something.

NEJE: What about your web site? The url is snappy: http://www. building19.com. Don't you think that if you get eyes onto the web page, they might also buy something?

Ellis: Our web site is bland and disgraceful. It is one of those things I haven't gotten around to do and frankly, I guess I'm waiting for some brilliant 19-year-old who's really into this stuff to come pounding on my door and say, "Let me do the web site." I'll give him or her all the support I can. Some things we do in print are good and, I think, a lot of that could be translated into a web site and probably improved upon. It could be a tremendous amount of fun and, I guess, I could do it myself if I had the time or inclination.

\section{NEJE: Do you know how?}

Ellis: Whatever you do with a pencil and paper you could do on the web site-just translate it. Someday when we have a 12-day snowstorm and I'm housebound and have nothing to do, l'll do it.

NEJE: Building \#19 is Jerry Ellis for the shoppers who come to your stores. Everything says Jerry Ellis: The ads say Ellis; the store signs say Ellis; the attitudes say Ellis. The shopper can't separate the two.

Ellis: There's a certain risk when you do that, and I guess there are some drawbacks. I used to write my own copy in the early days and the drawback is if Ellis gets involved in a scandal or runs off with Brigitte Bardot or whatever, you could destroy your business. Whereas, if the president of Macy's runs off with Brigitte... 
NEJE: But what's the likelihood of that happening?

Ellis: Oh, well...she calls a lot!

NEJE: You've developed your business by your own standards. The onlydawnside I can see is that if someone else has the business, they have to maintain that Jerry Ellis is still there, or they have to redesign the face of the business.

Ellis: Yeah, that is the real disadvantage. A long time ago, one of the big guys wanted to buy the company, but one of the drawbacks he found was that it was a one-man business at that time. Is it a one-person business anymore? I don't think so.

NEJE: It seems like you have generally been opposed to expansion. In fact, you suggested that compression would be good for the business. Is that accurate?

Ellis: Yes, up to a point. This is not a scientific business. This is an art, and it needs hands on. You have to go there, you have to be in a lot of stores. There's a limit to how many stores you can be in. I guess there was a period of time, maybe 10 years ago, when I thought expansion might be the right way to go.

\section{NEJE: Is that when you opened a lot of stores?}

Ellis: That's when I went to Rhode Island. I heard all these wonderful things about Warwick-a great shopping center, "everybody" was there. And, if everybody's there, maybe I should move there and find out if I'm good or if I'm lucky. So, I made a deal to take over three Kmarts. It was very complicated. One of the Kmarts was dark and in a mall that I owned. Nobody wants a dark store. So I figured l'd take that one and it would be good for the mall and for me.

NEJE: How closely are the fortunes of Building \#19 linked to the economy? Do you thrive in a good economy?

Ellis: We think that it's as close to a depression-proof business as you can get.

NEJE: I was thinking the reverse. Good economy, you might be in trouble.

Ellis: Possibly. People shop here for different reasons. But there usually comes a time when they have to shop here, and they know we have great credibility.

NEJE: Let me take you back again. So there you were in 1972. You had three stores, you were averse to expanding because, you claim, expansion will keep you off the golf course. But you just kept opening stores anyway.

Ellis: This bargain business kind of gets in your blood. I can't stand to see a bargain go to waste. I've bought property that I got a good price on. Actually, property that was a steal. I once paid $\$ 500,000$ for a lease in a shopping center that had an option to buy for $\$ 1$ million. I exercised it and it's now worth about $\$ 8$ to $\$ 9$ million. I bought one store for I think $\$ 500,000$ and got a $\$ 600,000$ mortgage on it. So there were great opportunities. It seemed to work out that about every two years we opened a store.

NEJE: So when we talk about your strategy of development for Building \#19, it's "when I see a great bargain and I can't pass it up, I buy it."

Ellis: Yes.

NEJE: It's opportunistic.

Ellis: Absolutely.

NEJE: Let me ask you about some turning points. Definitive points...highlights...lowlights.

Ellis: Certainly the Kmart decision was a turning decision. That was a serious decision. At about the same time we had the invasions of Wal-Mart, Home Depot, Christmas Tree Shops, and Job Lot. A lot of national stores came in which had not been here before, and the economy started to get better.

So that's one instance that if I had a second chance, I wouldn't do it. I tried to make that decision based on the fact that if I'm right, what can I win and if I'm wrong, what can I lose? I didn't lose anything.

\section{NEJE: Not a bad way to be wrong.}

Ellis: The rest of our turning points probably have something to do with major disasters with storms and things like that. When the floods hit in Wilkes-Barre and Scranton, Pennsylvania, we worked very hard and very long. It was a difficult period but we lived off that for a long time. When the hurricanes hit down in Gulfport, Mississippi, same thing. We shipped trailerloads of merchandise. It took us a long time to do and a long time to sell. When Hurricane Georges hit, we brought in 200 trailerloads of merchandise.

Those are really turning points, I think. Not only do you sell that merchandise, you gain some momentum. You get some people to come in who have never been to a Building \#19. And, if they like it, they have a pleasant experience, and they feel they got their money's worth or more, they keep coming in.

NEJE: I can see from talking to you that you have an uncomfortable feeling that the most profitable occasions for you are someone else's disasters. What's the impact on your workers, on you, on your management team?

Ellis: I don't think you ever get immune to it. It's very sad. I remember years ago, I was in Wilkes-Barre and we were cleaning out a department store in the downtown. The water had receded, we were pulling merchandise out of the 
under counter drawers. The drawers had swollen so I was forced to pop them open with a crowbar.

I was working with a nice lady who lived right on the riverbank. She was rather poor and had lost everything in the flood. She still had 6 payments on her refrigerator and 12 payments on the washing machine. And this lady had every intention of making those payments. It probably took her years and years and years to get back to where she was before the flood. That's pretty sad.

NEJE: So how do you keep so upbeat in the face of your good fortune being someone else's bad? It's really hard to put a face on this. It's so much easier when you don't put a human face on it. You talk about insurance losses, but sometimes you're there face-toface.

Ellis: We do what we can charity-wise, but there's not much you can really do. I'm not so thrilled doing it, but when the big insurance companies come to me, I have to be there. You have to take the bad to get the good.

\section{NEJE: So, what do you think was your smartest move?}

Ellis: Beyond my marriage license? [long pause] Maybe in the late 1960s, early 1970 s when we bought the windows from the John Hancock building. This gave us notoriety. You know, people didn't even know we were here, but after that they knew. [Editor's Note: The John Hancock Tower in Copley Square, Boston, was designed by I. M. Pei and was built in 1972-1975. The tower is glass from the bottom up. Unfortunately, in its first iteration, many windows fell to the street, and the tower had to be sheathed in plywood to protect pedestrians from injury.]

NEJE: And did you sell the windows? Or did you just keep them?

Ellis: No, no we sold a lot. We also broke a lot of them!

\section{NEJE: Big bucks or little bucks?}

Ellis: Great percentage margin, but not very much money. At the time, I thought it was big bucks. We did get some TV and newspaper coverage. It worked out pretty well.

\section{NEJE: Did you do some other dramatic things like that? \\ Ellis: Remember during the bicentennial when they float- ed that big cake in Baltimore harbor? Well, we bought the rest of the cake and brought it up here to serve with our free coffee.}

NEJE: People like that kind of stuff. Did a lot of people come into the store because of it?

Ellis: I don't even know if we advertised it. We just did it. Another fun thing comes to mind that we really ought to do again. We sold used Christmas cards and donated the proceeds to charity.

NEJE: Used Christmas cards? Like it says "Love, Steve and Ellen" inside?

Ellis: Yes, it was great fun.

NEJE: You paid money for used Christmas cards? Why would anybody buy used Christmas cards?

Ellis: Well, we would buy them if they said "Love, Steve and Ellen," but we wouldn't pay as much as if they just said "Love. Steve" or "Love, Ellen" because we could sell them easier. And, if the card was signed down near the bottom, we just cut that off! Or we would use White OutTM. The public had a lot of fun with it. It was a good time. And we got TV coverage and all that.

NEJE: So what's the next fun you have planned?

Ellis: I don't know. Nothing comes to mind. Of course, that's a lot easier when you're small.

NEJE: You've done some really neat smart moves in terms of publicity for Building \#19. On a more ticklish level, what are the dumbest things you've done?

Ellis: [Laughter] Did I tell you about my catsup adventure? Several years ago I got a call from the railroad that they had a carload of catsup in 5-gallon tins in Ohio. It had been refused because some of the cans were leaking. I was told we could recover at least 90 percent of the catsup.

I called somebody who makes those little packets of catsup and I arranged to sell it to him. I think I paid $\$ 1,200$. for the carload of catsup and I had it brought here to the shipyard to be unloaded, put it in trucks, and taken to this guy and be done with the deal.

But apparently a fly found out about it.

NEJE: A fly?

Ellis: A fly. And that fly told two other flies, and they told two flies, and pretty soion we had every fly in North America here to admire our catsup. And it just became a nightmare. I had people quit. We bought all kinds of protective clothing, we did everything. Finally, we hired a mobile car wash to come down and spray. Apparently, this car must have had a terrible ride because the seams were split on more cans than we had guessed-a large number of cans. And I think I lost $\$ 24,000$ on a $\$ 1,200$ investment. We had to pay to dump this and it was a terrible mess. You know, they're not all winners. That was probably my worst mistake.

NEJE: All in a day's work. Do you have a word of advice you'd like to leave our readers?

Ellis: [Laughter] I recognize that l've been very lucky. I just wish more people could enjoy the independence of having their own business. Even though it isn't always fun, by and large when I look at other people, I see how fortunate I am. 
If things go bad, that's my fault. But I can do something about it. How about people that work for big corporations? Regardless of how much money they make, somebody a thousand miles away makes a decision, they're out of a job, or their job changes. This, on the other hand, is pretty nice.
NEJE: Very few people are willing to take the risks involved.

Ellis: Well, I'm not sure it's risk taking. I don't take risksthe odds are stacked in my favor. And you only have to be right 51 percent of the time.

\section{NESE}

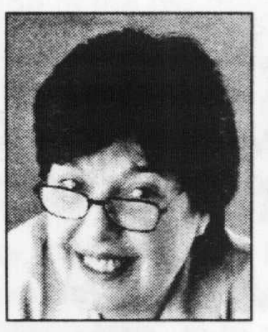

Dr. Gina Vega, assistant professor of management at Merrimack College, teaches the theory and practice of management, organizátional behavior, and business ethics. She has published articles in The Journal of Business Ethics, The Small Business Forum, Social Policy, and other journals and manuals. Her research interests focus on leadership, small business transitions, and human relations/communications issues. 